Original Research Paper

\title{
$\beta$-carotene Supplementation Does Not Improve Milk Yield and Milk Components of Saanen Goats
}

\author{
1,2 Dominic Lado Marino Gore and ${ }^{3 *}$ Khoboso Christina Lehloenya \\ ${ }^{1}$ Department of Animal and Wildlife Sciences, University of Pretoria, Hatfield, 0002, South Africa \\ ${ }^{2}$ Department of Animal Production, University of Juba, P.O. Box 82 Juba, South Sudan \\ ${ }^{3}$ Department of Agriculture, University of Zululand, Private Bag X1001, KwaDlangezwa 3886, South Africa
}

Article history

Received: 29-01-2020

Revised: 24-04-2020

Accepted: 12-05-2020

Corresponding Author:

Khoboso Christina Lehloenya

Department of Agriculture,

University of Zululand, Private

Bag X1001, KwaDlangezwa

3886, South Africa

E.mail: LehloenyaK@unizulu.ac.za

khoboso.lehloenya@gmail.com

\section{Introduction}

Feed supplements such vitamin E, vitamin C, carotene, selenium, zinc, vitamin A and manganese are considered to have antioxidant activities (Mardalena et al., 2011; Torsein et al., 2018). These antioxidants could improve health protection against free radicals as an attempt to prevent damage caused by oxidation process (Mardalena et al., 2011). As a result, causes improvement in protein, fat, somatic cell count and udder health (Sretenovic et al., 2007; Pulido et al., 2012).

Dairy products such as milk have high contents of vitamin-A and $\beta$-carotene which are stored in form of retinol in animals (Ullah et al., 2017). $\beta$-carotene with its function as an antioxidant can directly play a role in reduction of oxidative stress thus improving products quality and health status of animals (Castillo et al., 2005; 2006). Therefore, addition of $\beta$-carotene can play a crucial role in goat nutrition to enhance milk performance.

In ruminant animals, however, there is species difference in terms of $\beta$-carotene transformation. $\beta$ carotene is adequately converted in animals like sheep and goats, while in cattle, they have inadequate capability in converting $\beta$-carotene (McDowell, 2000). Despite these species differences, however, most studies in the literature which examined influence of $\beta$-carotene on milk and quality were done in dairy cattle. There are however, limited studies in goats on the influence of $\beta$ carotene supplementation on milk yield and milk composition. Therefore, the current study aimed at evaluating the effect of supplemental $\beta$-carotene on milk yield and milk composition for Saanen goats.

\section{Materials and Methods}

\section{Ethical Approval}

This study was conducted with approval by the University of Pretoria animal ethics committee (Project no.EC108-14).

\section{Experimental Site}

The study was carried out at the University of Pretoria experimental farm, South Africa. The coordinates of the farm at latitude $25^{\circ} 44^{\prime} 30^{\prime \prime} \mathrm{S}$ and longitude $28^{\circ} 15^{\prime} 30^{\prime \prime} \mathrm{E}$, with an elevation of $1360 \mathrm{~m}$ above sea level. The area is characterised by warm and humid condition in summer and dry, cold and sunny in winter with an average rainfall of $650 \mathrm{~mm}$ in summer (Van Niekerk et al., 2009). 
Table 1: Feed ingredients for the total mixed ration

\begin{tabular}{lll}
\hline Ingredients & Dry matter\% & Quantity in kg/animal \\
\hline Lucerne hay & 43.81 & 1.600 \\
Eragrostis curvula hay & 24.10 & 0.900 \\
Maize meal & 16.06 & 0.600 \\
Molasses & 9.05 & 0.350 \\
Protein concentrate & 6.98 & 0.250 \\
Total & 100.00 & 3.700 \\
\hline
\end{tabular}

Experimental Animals, Feeding and Management System

Sixty (60) females Saanen goats between one and six years and also of parity between one and four were used in this experiment. The animals were kept under intensive system and were fed on total mixed ration as shown in (Table 1). The protein concentrate was sourced from a commercial company. Throughout the duration of the experiment water was given at free access. The mastitis test was done daily as a routine husbandry practices using California Mastitis Test (CMT) and ranked according to increase in viscosity from 1 to 5 . The highest viscosity CMT 5) is more or less correlated to the highest SCC. The animals that were used for the experiment had acceptable values.

\section{Experimental Design and Treatments}

The does were assigned in to two groups of $\beta$ carotene supplemented and non-supplemented considering their weight and parity in a completely randomised design and each group comprised thirty (30) does. The average body weight and parity for control and supplemented groups were $47.10 \pm 3.07 \mathrm{Kg}$ and $46.67 \pm 3.07 \mathrm{Kg}$ and $2.50 \pm 0.23$ and $2.56 \pm 0.23$, respectively and did not differ significantly.

\section{$\beta$-carotene Supplementation}

Animals in supplemented group were orally administered $\beta$-carotene (100 mg/head/day) (Pennville Pty Ltd, South Africa) for a duration of 58 days which commenced four (4) weeks prior to synchronisation of oestrus. Again, following the drying off period, animals were given $\beta$-carotene $(50 \mathrm{mg} /$ head/day $)$ for a duration of approximately 40 days. The company indicated that each $10 \mathrm{~g}$ paste contained $100 \mathrm{mg} \beta$-carotene. The control group received water as placebo with similar quantities as in the treatment group.

\section{Oestrus Synchronisation Protocols}

All does were kept away from bucks for a period of one (1) month prior to the onset of the experiment. All does were synchronised using Controlled Internal Drug Releasing device (CIDR) containing $0.3 \mathrm{~g}$ progesterone (Pfizer, New Zealand). The device was implanted intravaginal and allowed for a duration of 11 days. At CIDR removal, all does were injected with $150 \mu \mathrm{g}$ cloprostenol and one group injected $300 \mathrm{IU}$ of equine Chorionic Gonadotropin (eCG) (Intervet ScheringPlough Animal Health, South Africa) while another group introduce to Male effect.

\section{Semen Collection and Artificial Insemination (AI) Semen Collection}

An electro ejaculator (Ramsem, South Africa) was used to collect semen from bucks as described by Sundararaman et al. (2007) with few modifications. Briefly, after the probe was inserted inside the rectum, the buck was massaged and the machine button was pressed producing a voltage of 3-5 volts. After pressing the button, it was held for 4-5 sec and again returned to 0 . Semen mass motility was analysed according to the procedures by Dogan et al. (2005). From each semen sample collected, $10 \mu \mathrm{L}$ semen on was put on glass slide and then examined on a microscope (Olympus $\mathrm{C} \times 21$ ). Semen samples with motility score of three (3) and above were used.

\section{Artificial Insemination}

The procedures for artificial insemination followed were as described by (Steyn, 2005). Each doe was inseminated with fresh undiluted semen of $0.2 \mathrm{~mL}$ with a concentration of $300-800 \times 106$ sperm. Cervical insemination was carried out in all does twice at fixed times of $48 \mathrm{~h}$ and $60 \mathrm{~h}$ after CIDR removal (Motlomelo et al., 2002).

\section{Milk Collection and Analysis}

\section{Milk Collection}

Milking of all goats was done daily (morning and evening) using milking machine. Following kidding, five (5) does in each group were selected and milk colostrum samples were taken once a day in the morning for duration of three (3) days. Similarly, milk samples were taken once a week for a duration of four (4) weeks from the same five does used for colostrum collection. Milk from each goat was analysed separately to have 5 values per collection and therefore, milk samples were not pooled. Daily milk yield was collected for a period of over 30 days starting 5 days after kidding from all the goats leading to four collections. The milk samples were kept in vials (Lactolab Pty Ltd). The vials contained a Broad Spectrum Microtabs II tablet (Advanced Instruments, Massachusetts, USA), a preservative preventing growth of bacteria, mold and yeast.

\section{Milk Analysis}

Milk fat\%, protein \%, lactose $\%$ and Somatic Cell Counts (SCC) were analysed in both the colostrum and 
milk samples by Lactolab Pty Ltd laboratory at the Agricultural Research Council, Irene, South Africa. The somatic cell count was analysed using Cytometer while protein, fat and lactose were analysed using Spectrometer (Minnesota, USA).

\section{Statistical Analysis}

The data collected for milk yield, fat, protein and lactose and SCC were analysed with one-way analysis of variance for repeated measures using PROC GLM procedure of SAS (version 9.4).

The model fitted was:

$$
Y_{i j}=\mu+T_{i}+E_{i j}
$$

Where:

$Y_{i j}=$ Observation on the dependent variables

$\mu=$ Overall mean

$T_{i}=$ Treatment effect

$e_{i j k}=$ Random error

\section{Results}

Supplemental $\beta$-carotene did not influence milk yield, protein $\%$, lactose $\%$, fat $\%$ and SCC. The result showing the influence of $\beta$-carotene supplementation on milk yield, protein $\%$, lactose $\%$, fat $\%$ and SCC is shown as in (Table 2).

Supplemental $\beta$-carotene did not significantly $(P>0.05)$ influence the average daily and total milk yield over 30-day period during early lactation. However, numerically, the total milk yield and daily milk yield tended to be higher in the treatment group compared to the control group but not significant. Milk fat, protein, lactose and the SCC did not differ significantly $\quad(P>0.05) \quad$ between $\quad \beta$-carotene supplemented group and non-supplemented group. Similarly, colostral fat, protein, lactose and the SCC did not differ significantly $(P>0.05)$ between $\beta$ carotene supplemented group and non-supplemented group (Table 3). Similarly, milk lactose percentage tended to be higher in $\beta$-carotene supplemented group than in non-supplemented group but not significant. Moreover, numerically, the treatment group tended to have lower SCC in $\beta$-carotene supplemented group than in non-supplemented group.

Milk colostrum fat, protein, lactose and SCC did not differ significantly between $\beta$-carotene supplemented group and non-supplemented group (Table 2). However, numerically, protein and fat and somatic cell counts tended to be higher in the $\beta$-carotene supplemented than in the non-supplemented group but the differences were not statistically significant.
Table 2: Milk yield and composition (Mean \pm SE) of Saanen goats supplemented with $\beta$-carotene

\begin{tabular}{lll}
\hline Parameters & Treatment & Control \\
\hline $\begin{array}{l}\text { Milk yield (30 days } \\
\text { period), kg }\end{array}$ & $108.78 \pm 5.48^{\mathrm{a}}$ & $107.30 \pm 6.13^{\mathrm{a}}$ \\
Milk yield, kg/day & $3.63 \pm 0.18^{\mathrm{a}}$ & $3.58 \pm 0.20^{\mathrm{a}}$ \\
Milk fat\% & $3.76 \pm 0.23^{\mathrm{a}}$ & $4.06 \pm 0.23^{\mathrm{a}}$ \\
Milk protein\% & $3.29 \pm 0.08^{\mathrm{a}}$ & $3.39 \pm 0.08^{\mathrm{a}}$ \\
Milk lactose\% & $4.57 \pm 0.05^{\mathrm{a}}$ & $4.54 \pm 0.05^{\mathrm{a}}$ \\
Milk SCC, $\times 1000$ cells $/ \mathrm{mL}$ & $881.55 \pm 207.50^{\mathrm{a}}$ & $930.53 \pm 207.50^{\mathrm{a}}$ \\
\hline \multicolumn{2}{l}{ Means with similar letters do not differ significantly }
\end{tabular}

Table 3: Colostrum composition (Mean \pm SE) of Saanen goats supplemented with $\beta$-carotene

\begin{tabular}{lll}
\hline Parameters & Treatment & Control \\
\hline Colostral fat\% & $6.89 \pm 0.47^{\mathrm{a}}$ & $6.56 \pm 0.45^{\mathrm{a}}$ \\
Colostral protein $\%$ & $7.33 \pm 0.54^{\mathrm{a}}$ & $6.30 \pm 0.52^{\mathrm{a}}$ \\
Colostral lactose\% & $3.62 \pm 0.14^{\mathrm{a}}$ & $3.73 \pm 0.14^{\mathrm{a}}$ \\
Colostral SCC, & $2213.86 \pm 344.33^{\mathrm{a}}$ & $2030.10 \pm 332.66^{\mathrm{a}}$
\end{tabular}

$\times 1000$ cells $/ \mathrm{mL}$

Means with similar letters do not differ significantly

\section{Discussion}

$\beta$-carotene is among antioxidants that have been shown to play important role in improving milk composition and health status of udder. The present study hypothesised that that supplementing goats with $\beta$-carotene would increase milk yield and improve milk composition and quality of Saanen goats. However, supplemental $\beta$-carotene did not improved milk yield, milk composition and quality of Saanen goats during drying off period.

With few previous studies on the influence of $\beta$ carotene on milk yield, milk composition and quality in goats, the current study could not compare or contrast its findings with findings from similar species. Similar studies, however, have been done in other ruminant species. In sheep, supplemental $\beta$-carotene did not influence milk yield (Brozos et al., 2007). In addition, dairy cows supplemented with $\beta$-carotene did not affected milk yield (Bindas et al., 1984; Rakes et al., 1985; Wang et al., 1988; De Ondarza et al., 2009; De Ondarza and Engstrom, 2009; Kaewlamun et al., 2011; 2012; Oliveira et al., 2015). These studies are consistent with the finding of the present study with regard to milk yield. Contrarily, some studies reported that $\beta$-carotene supplementation has a positive effect on milk production in heat stress cows (Arechiga et al., 1998; Chawla and Kaur, 2004). These disparities between studies on the effect of supplemental $\beta$-carotene on milk yield could be ascribed to differences in amount of $\beta$-carotene in the diet and blood and level, time and period of $\beta$-carotene supplementation (Kaewlamun et al., 2011). It is imperative that sheep and goats adequately convert dietary $\beta$-carotene (McDowell, 2000). Therefore, the ineffectiveness of supplemental $\beta$-carotene in improving milk yield from the 
current study could be ascribed to insufficient amount of $\beta$ carotene in the mammary gland and thus led to lack of its antioxidant influence.

For the milk composition, previous studies with dairy cows reported conflicting results on the influence of $\beta$ carotene on milk components. In line with the current study, it was reported that supplemental $\beta$-carotene has no positive effect on milk fat, protein and lactose (Kaewlamun et al., 2011; 2012; Machpesh, 2013; Oliveira et al., 2015). Also, it has been noted that supplemental $\beta$-carotene did not influence milk protein but increase milk fat\% in cows (De Ondarza et al., 2009). Conversely, supplemental $\beta$-carotene reduced milk fat\% (Oldham et al., 1991).

In agreement with the current study, supplemental $\beta$ carotene did not influence milk SCC in cattle (Wang et al., 1988; Oldham et al., 1991; De Ondarza et al., 2009; Kaewlamun et al., 2011; 2012; Oliveira et al., 2015). In disagreement with the current finding, other studies had reported that supplemental $\beta$-carotene reduced milk SCC in cattle (Rakes et al., 1985; Wang et al., 1988). Ineffectiveness of supplemental $\beta$-carotene in reducing SCC in the current study could be due to the fact that goats convert $\beta$-carotene adequately and as a result mammary glands did not absorb enough $\beta$-carotene to exert its antioxidant activity. This could be ascribed to levels of supplemental $\beta$-carotene in the current study.

Although $\beta$-carotene supplementation did not improved milk yield and milk components in the current study, other antioxidants however, have been reported to affect milk yield and milk components. Milk yield, protein and fat were increased and somatic cell counts were reduced in goats supplemented with Se-VitE (Tufarelli and Laudadio, 2011; Zhang et al., 2018). Additionally, milk yield and fat were improved in goats supplemented with fat with exception of protein (Al-Dabbas and Hawari, 2011). Moreover, the combined supplementation of $\alpha$-tocopherol plus selenium decreased the relative proportions of short chain fatty acids and medium-chain fatty acids and increased that of long chain fatty acids in milk fat (Pulido et al., 2012).

\section{Conclusion}

Supplemental $\beta$-carotene did not influence milk yield and composition of Saanen goats during the drying off period. Further research is warranted on the effect of different levels of $\beta$-carotene on milk yield and composition and on concentration of $\beta$-carotene and vitamin $\mathrm{A}$ in blood and milk at different stages of lactation in goats.

\section{Acknowledgment}

The authors acknowledge the Office of International Research, Education and Development (OIRED) through
Rebuilding Higher Education in Agriculture (RHEA) project implemented by Virginia Tech and Borlaug Higher Education for Agricultural Research and Development (BHEARD) project implemented by Michigan State University under the umbrella of USAID for providing financial assistance for this study as well as the University of Pretoria for providing the experimental animals.

\section{Funding Information}

This material is based upon work supported by the United States Agency for International Development, as part of the Feed the Future Initiative, under the CGIAR Fund, award number BFS-G-11-00002 and the predecessor fund the Food Security and Crisis Mitigation II grant, award number EEM-G-00-04-00013.

\section{Author's Contributions}

Dominic Lado Marino Gore: Contributed on the original ideas of the manuscript, data collection, analysis and interpretation and manuscript write up.

Khoboso Christina Lehloenya: Contributed on the original ideas and preparation of the manuscript.

\section{Ethics}

The authors confirm that the manuscript has not been published or not under consideration for publication in other journals. We also confirm that there is no conflict of interest and that all the authors have agreed on the order of authors listed in the manuscript.

\section{References}

Al-Dabbas, F.M. and A.D. Hawari, 2011. The effect of fat supplementation in shami goat diets on milk production and composition, does body weight and growth performance of their Suckling Kids. Pak. J. Bio. Sci., 14: 725-728. DOI: $10.3923 /$ jjbs.2011.725.728

Arechiga, C.F., C.R. Staples, L.R. McDowell and P.J. Hansen, 1998. Effects of timed insemination and supplemental $\beta$-carotene on reproduction and milk yield of dairy cows under heat stress. J. Dairy Sci., 81: 390-402. DOI: 10.3168/Jds.S0022-0302(98)75589-4.

Bindas, E.M., F.C. Gwazdauskas, R.J. Aiello, J.H. Herbein and M.L. McGilliard et al., 1984. Reproductive and metabolic characteristics of dairy cattle supplemented with $\beta$-carotene. J. Dairy Sci., 67: 1249-1255. DOI: 10.3168/Jds.S0022-0302(84)81431-9. 
Brozos, C.N., E. Kiossis, G.C. Fthenakis, G. Tsousis and C. Boscos, 2007. Supplementation of lactating ewes with glucogenic preparation or beta-carotene in midto late lactation on subsequent milk yield and luteinizing hormone secretion. Can. J. Anim. Sci., 87: 185-90. DOI: 10.4141/A06-080

Castillo, C., J. Hernandez, A. Bravo, M. Lopez-Alonso and V. Pereira et al., 2005. Oxidative status during late pregnancy and early lactation in dairy cows. Vet. J., 169: 286-292.

DOI: $10.1016 /$ j.tvj1.2004.02.001

Castillo, C., J. Hernandez, I. Valverde, V. Pereira and J. Sotillo et al., 2006. Plasma Malonalde-hyde (MDA) and Total Antioxidant Status (TAS) during lactation in dairy cows. Res. Vet. Sci., 80: 133-139.

DOI: $10.1016 /$ j.rvsc.2005.06.003

Chawla, R. and H. Kaur, 2004. Plasma antioxidant vitamin status of periparturient cows supplemented with $\alpha$-tocopherol and $\beta$-carotene. Anim. Feed Sci. Technol., 114: 279-285.

DOI: 10.1016/j.anifeedsci.2003.11.002.

De Ondarza, M.B. and M. Engstrom, 2009. Production and reproduction responses of dairy cows to supplemental $\beta$-carotene. Proceedings of the Penn State Dairy Cattle Nutrition Workshop, Nov. 11-12, Grantville, PA.

De Ondarza, M.B., J.W. Wilson and M. Engstrom, 2009. Case study: Effect of supplemental $\beta$ carotene on yield of milk and milk components and reproduction of dairy cows. Professional Anim. Sci., 25: 510-516.

DOI: $10.15232 / \mathrm{S} 1080-7446(15) 30742-7$

Dogan, I., Z. Nur, U. Gunay, H. Sagirkaya and M.K. Soylu et al., 2005. Estrous synchronisation during the natural breeding season in Anatolian black does. Vet. Med. Czech, 50: 33-38.

DOI: $10.17221 / 5594-V E T M E D$

Kaewlamun, W., M. Okouyi, P. Humblot, D. Remy and M. Techakumphu et al., 2012. Effects of a dietary supplement of $\beta$-carotene given during the dry period on milk production and circulating hormones and metabolites in dairy cows. Rev. Med. Vet., 163: 235-241.

Kaewlamun, W., M. Okouyi, P. Humblot, M. Techakumphu and A.A. Ponter, 2011. Does supplementing dairy cows with $\beta$-carotene during the dry period affect postpartum ovarian activity, progesterone and cervical and uterine involution? Theriogenology, 75: 1029-38.

DOI: $10.1016 /$ j.theriogenology.2010.11.010

Machpesh, G., 2013. An investigation of the betacarotene status of Holstein cows in South Africa. MSc Thesis, University of Pretoria, South Africa.
Mardalena, M., L. Warly, E. Nurdin, W.S.N. Rusmana and F. Fariza. 2011. Milk quality of dairy goat by giving feed supplement as antioxidant source. J. Indonesian Trop. Anim. Agric., 36: 205-212.

DOI: $10.14710 /$ jitaa.36.3.205-212

McDowell, L.R., 2000. Vitamins in animal and human nutrition. Iowa State University Press, Ames.

Motlomelo, K.C., J.P.C. Greyling and L.M.J. Schwalbach, 2002. Synchronisation of oestrous in goats: The use of different progestagen treatments. Small Rum. Res., 45: 45-49.

DOI: 10.1016/S0921-4488(02)00113-X.

Oldham, E.R., R.J. Eberhart and L.D. Muller, 1991. Effects of supplemental vitamin a or $\beta$-carotene during the dry period and early lactation on udder health. J. Dairy Sci., 74: 3775-3781.

DOI: 10.3168/Jds.S0022 0302(91)78569-X

Oliveira, R.C., B.M. Guerreiro, N.N. Morais, R.L. Araujo and R.A. Pereira et al., 2015. Supplementation of prepartum dairy cows with betacarotene. J. Dairy Sci., 98: 6304-6314.

DOI: $10.3168 /$ jds.2014-9037

Pulido, E., F.J. Giráldez, R. Bodas, S. Andrés and N. Prieto, 2012. Effect of reduction of milking frequency and supplementation of vitamin $\mathrm{E}$ and selenium above requirements on milk yield and composition in Assaf ewes. J. Dairy Sci., 95: 3527-3535. DOI: 10.3168/jds.2011-5048

Rakes, A.H., M.P. Owens, J.H. Britt and L.W. Whitlow, 1985. Effects of adding beta-carotene to rations of lactating cows consuming different forages. J. Dairy Sci., 68: 1732-1737.

DOI: 10.3168/Jds.S0022-0302(85)81019-5.

Sretenovic, L.J., S. Aleksic, M.P. Petrovic and B. Miscevic, 2007. Nutritional factors influencing improvement of milk and meat quality as well as productive and reproductive parameters of cattle. Biotechnol. Anim. Husbandry, 23: 217-226. DOI: $10.2298 / \mathrm{BAH} 0701217 \mathrm{~S}$

Steyn, J.J., 2005. Application of Artificial Insemination (AI) on commercial sheep and goat production. Ramsem Company Ltd, South Africa.

Sundararaman, M.N., J. Kalatharan and M.J. Edwin, 2007. Attempts to achieve semen collections from incapacitated Boer bucks by electro-ejaculation. Asian J. Anim. Vet. Adv., 2: 244-246.

DOI: 10.3923/ajava.2007.244.246

Torsein, M., A. Lindberg, C. Svensson, S.K. Jensen and C. Berg et al., 2018. $\alpha$-Tocopherol and $\beta$-carotene concentrations in feed, colostrum, cow and calf serum in Swedish dairy herds with high or low calf mortality. Acta Vet. Scand. 60: 7-7.

DOI: $10.1186 / \mathrm{s} 13028-018-0361-0$ 
Tufarelli, V. and V. Laudadio, 2011. Dietary supplementation with selenium and vitamin E improves milk yield, composition and rheological properties of dairy Jonica goats. J. Dairy Res., 78: 144-148. DOI: $10.1017 /$ S0022029910000907

Ullah, R., S. Khan, H. Ali, M. Bilal and M. Saleem, 2017. Identification of cow and buffalo milk based on Beta carotene and vitamin-A concentration using fluorescence spectroscopy. PLoS ONE, 12: e0178055-e0178055.

DOI: 10.1371/journal.pone.0178055

Van Niekerk, W.A., A. Hassen, L.D. Snyman, N.F.G. Rethman and R.J. Coertze, 2009. Influence of mineral composition and rumen degradability of Atriplexnummularia (Hatfield Select F1) plants on selection preference of sheep. Afri. J. Range For. Sci., 26: 91-96.

DOI: 10.2989/Ajrfs.2009.26.2.8.851
Wang, J.Y., F.G. Owen and L.L. Larson, 1988. Effect of beta carotene supplementation on reproductive performance of lactating Holstein cows. J. Dairy Sci., 71: 181-186.

DOI: 10.3168/Jds.S0022-0302(88)79540-5.

Zhang, L., X.R. Liu, J.Z. Liu, X.P. An and Z.Q. Zhou et al., 2018. Supplemented organic and inorganic selenium affects milk performance and selenium concentration in milk and tissues in the Guanzhong dairy goat. Biol. Trace Elem. Res., 183: 254-260. DOI: $10.1007 / \mathrm{s} 12011-017-1112-1$ 